\title{
Academic performance and bullying in socially vulnerable students
}

\author{
Marcela Almeida Zequinão1, Allana Alexandre Cardoso², Jorge Luiz da Silva ${ }^{3}$, Pâmella de Medeiros², \\ Marta Angélica Lossi Silva ${ }^{3}$, Beatriz Pereira', Fernando Luiz Cardoso ${ }^{2}$
}

\begin{abstract}
Introduction: School bullying is characterized by over time repetitiveness of aggression, with the intentionality in injure or cause suffering to another and the imbalance of power between the participants. This is not a current phenomenon, because the recurring situations of violence between peers at school probably in recurrent along the human history. Involvement in school bullying can have negative consequences, including for the students' teaching-learning process in which those involved may have troubles as failure, dropout, as well as, episodes of indiscipline.
\end{abstract}

Objective: to identify the school performance of children and adolescents in social vulnerability situation, as well as, to analyze the possible relationships of this performance with participation in situations of violence that characterize school bullying.

Methods: participated 375 primary school children and adolescents of both sexes, aged between 8 and 16 years. The instruments used were: School performance test, Sociometric Scale and Questionnaire for the Study of Violence Among Peers. Data were analyzed using ANOVA Two-way test and Spearman correlation.

Results: the present study indicated that children and adolescents in social vulnerability situation presented poor school performance that means results below expected levels for their respective school years regards to the three subtests: writing, arithmetic and reading, in both sexes and in different age groups. In an intra and extra analysis group, there was a significant difference between females' children and adolescent in all subtests. However, the same was not observed among boys. There was also a relationship between poor school performance and participation in bullying situations, in which it was found that the score on the writing subtest was negatively correlated with practice aggression and witnessing violence at school. A similar result occurred in relation to the reading subtest. The score arithmetic subtest, in turn, correlated negatively with the three forms of participation in situations of school violence: to assault, suffer abuse and witnessing violence against colleagues. Finally, the total score obtained in TDE negatively correlated up significantly with practice aggression and witnessing violence.

Conclusion: Based on the results of this manuscript, it was found that most children and adolescents in socially vulnerable investigated in this study showed school performance level considered lower than expected for their year attending. Allied to these results, it was found that teenage girls showed better performance than children of the same sex. Moreover, there is relationship between poor school performance and participation in bullying situations in different roles: victim, bully and bystander.

Keywords: educational status, bullying, vulnerable populations.

\section{INTRODUCTION}

School bullying is characterized by the repetition of aggression over time, by the intentional injuring or causing suffering to another, and by the imbalance of power between the involved parts ${ }^{1}$. It does not represent a recent problem, because the recurring situation of violence among peers at school has probably accompanied the history of this institution.

Bullying constitutes a social and grouped phenomenon, all the behaviours of the students involved (victims, bullies and bystanders), as well as the other members of the school community affect its genesis, continuation, and/ or interruption. Similarly, the identification of the nuances presented in different sociocultural realities is of fundamental importance for the prevention and confrontation of singular mode, in accordance with the characteristics presented by each school and specific location ${ }^{2}$.

In Brazil, a survey of the prevalence of this type of violence carried out in 2002 showed that 40.5 per cent of a sample of 5,500 students were involved in bullying situations, with the profiles of victims $(16.9 \%)$, bullies

\footnotetext{
1 Universidade do Minho (UM)

2 Universidade do Estado de Santa Catarina (UDESC)

3 Universidade de São Paulo (USP)

Corresponding author: marcelazequinao@gmail.com
}

Suggested Citation: Zequinão MA, Cardoso AA, Silva JL, Medeiros P, Silva MAL, Pereira B, Cardoso FL. Desempenho escolar e bullying em estudantes em situação de vulnerabilidade social. J Hum Growth Dev. 2017; 27(1): 19-27. DOI: http://dx.doi.org/10.7322/jhgd.127645 Manuscript submitted: 2016, accepted for publication May 2016 
(12.7\%), and bully-victims $(10.9 \%)^{3}$. In 2009, another national investigation identified its widespread occurrence, especially with regard to the testimony of those involved in bullying situations, since $70 \%$ of a group of 5,168 students reported having witnessed scenes of this phenomenon among their peers ${ }^{4}$. In 2012, the National Survey of School Health (NSSH) in its second edition, carried out a survey, with a sample of 109,104 students from public and private schools in the 27 Brazilian States, that mapped the phenomenon today, revealing that $7.2 \%$ of students were victims of bullying and $20.8 \%$ were bullies ${ }^{5}$.

As can be noticed, the prevalence data indicate that bullying is a problematic concern. The consequences and negative impacts it causes to students have also been widely documented by the specialized literature. In general, these consequences are encompassed in three groups and refer to health, psychosocial development, and the teaching-learning process. With regard specifically to the teaching-learning process, the literature suggests that the students involved may show poor performance, be unhappy at the school or drop out, as well as episodes of indiscipline ${ }^{6}$.

In the school context, the victims often miss school without reason, perform poorly, demonstrate insecurity when being in public and prefer to keep away from peers. The attackers already wield power that can even help in the assaults, and are responsible for installing a climate of insecurity and fear in the schools. In this way, the condition of school failure is related to all students involved in bullying situations ${ }^{7}$.

According to Felix, Alamillo, and Ruiz ${ }^{8}$, in countries with developing economies, this reality seems to be particularly aggravated, not only as regards to the levels and rates of occurrence of the phenomenon, but also by the low incorporation of this issue in public policies, cross-curricular practices, and even by the field of science. The recent character of the investigations of bullying in developing countries represents a misconduct of those considerations, due to the limited amount of publications about the theme. Nevertheless, is necessary to consider that children, in adverse situations of life - economic, social, family or personal - may face learning disabilities. These difficulties can be long lasting or fleeting, of greater or lesser intensity, and lead to other problems in schooling, such as poor performance, and unhappiness, and in more serious situations, dropping out ${ }^{9}$.

Furthermore, difficulties in school are associated with other behavioural and emotional problems. Children with learning disabilities and behavioural problems are generally characterised as being less involved in schoolwork, as they are a vulnerable group that is at risk of getting involved in school bullying ${ }^{3}$.

The poor performance is related to how students participate in bullying situations as victims, bullies and bystanders ${ }^{10}$. A gap in the literature is the absence of studies that investigate the relationship between academic performance and bullying in the most vulnerable populations, whereas both differentiated characteristic variables depending on the social context under investigation. In the Brazilian context, variations in the quality of public education and the inequalities between the social strata, especially, are two problems that allow us to consider the school as a social product that is unevenly distributed ${ }^{11}$.

Thus, there are localities or regions marked by higher levels of social inequality and access to services with higher quality and whose inhabitants are in a situation of social vulnerability, which means they "do not have or are unable to use material and immaterial assets that would allow the individual or social group dealing with poverty" $"$. Access to information and knowledge about school quality, reflected in learning and school performance, can help vulnerable students to cope better with or overcome this situation, considering that experiences at school contributes to different developmental trajectories of children and adolescents, which has a strong impact on their lives in the future ${ }^{13}$.

In this context, bullying is also found, because a better school performance hampers involvement in violence at school $^{10}$. Thus, the objective of this study is to identify the school performance of children and adolescent residents in communities considered as socially vulnerable, as well as analyse the possible relationships between school performance and participation in the situations of violence that characterize bullying (victimization, perpetrating aggression, and witnessing violence).

\section{METHODS}

\section{Participants}

The participants of this descriptive cross-sectional study with intentional sampling were 375 children and adolescents from the third to the seventh grade of primary school, students from two public schools located in the metropolitan area of the city of Florianópolis, Santa Catarina, Brazil. According to the Statute of the Child and Adolescent, a person counts as a child until 12 years of age, and the adolescent age-range is between 12 to 18 years of age. In terms of characterization, the participants were between 8 and 16 years of age, and among children the average age was 10.3 years for boys $(n=123)$ and 9.8 years for girls $(n=132)$, while for teenagers were $12.77(n=83)$ and $12.97(\mathrm{n}=70)$ respectively.

The school mobility of the participants proved to be equivalent for both genders and age groups, with average frequency of approximately 2.5 schools. Regarding skin colour, among the children the boys stated that they were white $(65.0 \%)$, light dark $(17.9 \%)$, black $(11.4 \%)$, and mixed (5.7\%), and girls stated that they were white $(75.0 \%)$, light dark $(15.9 \%)$, black $(7.6 \%)$, and mixed $(1.5 \%)$. Among teenagers, the boys stated that they were white $(73.5 \%)$, dark light $(13.3 \%)$, black $(7.2 \%)$, and mixed $(6.0 \%)$, while the girls were white $(70.0 \%)$, light dark (15.7\%), black (11.4\%), and mixed (2.9\%).

\section{Instruments}

The School Performance Test-TDE ${ }^{14}$, which assesses the level of academic performance in elementary school until $6^{\text {th }} / 7^{\text {th }}$ grade. It consists of three subtests: reading, writing, and arithmetic. The sum of the scores of each subtest results in a total score, which allows a classification of students' performance in three levels: top, middle, 
and bottom, according to each series/school year attended. A sociometric scale ${ }^{15}$, an instrument consisting of questions concerning daily life in the classroom, involving questions concerning the characteristic behaviour of students involved in school bullying situations as either victims and aggressors. Each participant indicates the names of three classmates who are more involved in the situations described. Thus, all students had two scores, one for assault and one for victimisation, generated by the number of times they have been cited, which facilitated the classification of students as either victims or aggressors.

A questionnaire for the study of violence among peers ${ }^{16}$, structured in closed issues and those pertaining to have been a bystander; the questions are answered using a 5-point Likert scale, where $1=$ never, $2=$ little, $3=$ sometimes $4=$ often, $5=$ always. With the sum of points of all issues, each participant obtained a score for participation in school bullying as a bystander.

\section{Procedures}

To carry out this research authorization was obtained from the Municipal Department of Education and the schools' administration offices. The recommendations and guidelines of resolution $466 / 2012$ by the National Health Council were followed at every stage of the research. The research project was first submitted and approved by the Research Ethics Committee of the Universidade do Estado de Santa Catarina - UDESC (Protocol \# 5439/2011).

Based on the number of children and adolescents participating in a social project that meets socially vulnerable students in the metropolitan region of Florianopolis, a sample size was calculated assuming an alpha of 0.5 and $50 \%$ power. From the sample calculation, the minimum required was 316 participants. The final sample size was 375. The selection of the two schools participating in the study was intentional, for reasons of accessibility and for participating in the social project.

Prior to the data collection, the children and adolescents received detailed information about the research. Only students who expressed willingness to cooperate with the investigation and presented a signed an informed consent letter participated in the study. The collection occurred in schools, during school hours. To evaluate the school performance, participants responded to the School Performance Test (TDE). Then the Sociometric Scale was filled out, with a view to identifying the roles they played in relation to bullying. Later, to check if bullying in school situations testified, the questionnaire concerning violence among peers was answered. The instruments were applied and supervised by two researchers.

\section{Analysis of the data}

Initially, an exploratory analysis of the data was performed, in order to summarize the information obtained in the study. The qualitative variables were described in terms of absolute frequency and percentage, since the quantitative variables are described by mean and standard deviation.

To achieve the goals of the study we decided to use two-factor analysis of variance (ANOVA-Two way) to compare the effect of gender and the difference between children and adolescents (age group). The method for analysing variance is based on partitioning the total variance of a particular answer (dependent variable) into two parts: the first in the regression model (in this case, and extra-group gender and intra-group age group) and the second due to waste (errors) (within the groups). The higher the first is in relation to the second, the more evidence there is with respect to the difference between the averages of the groups under study (gender and age group). This model has assumed that their waste has a normal distribution with a mean 0 and variance. This assumption was checked in every analysis carried out; the results were obtained with the aid of the SAS ${ }^{\circ} 9$ software, through the PROCEDURE GLM.

Related to the roles of participation in situations of violence at school and school performance measures the Spearman's rank correlation coefficient was used, which quantifies the association between two quantitative variables. This coefficient varies between -1 and 1 . The value 0 (zero) means that there is no linear relationship, the value 1 indicates a perfect linear relationship and the -1 value also indicates a perfect linear relationship, but reverse, i.e. when one of the variables increases the other decreases. The closer you are to 1 or -1 , the stronger the linear association between two variables. The results were obtained with the aid of the SAS ${ }^{\circledR} 9.0$ software, through the PROCEDURE CORR. The graphics that make up the correlation matrix were built with the aid of the $\mathrm{R}$ software (version 3.1.3). In every analyses a significance level of $5 \%$ was used.

\section{RESULTS}

In the assessment made by the School Performance Test, the highest percentage of students was in the lower level of school performance expected for their grade, in both genders and different age groups, in all three subtests that comprise the instrument: writing, arithmetic and reading. The lowest performance occurred in the arithmetic subtest for both boys and for girls, of different ages.

On the other hand, the reading subtest showed the best scores, although it was also below average for most students surveyed, for both females and males. The small oscillation in scores of subtests that contributed to total score of SPT also reflects the low school performance shown by the participants of the survey, as shown in table 1 .

A quantitative intra and extra-group analysis of the raw scores of all and the total score of the subtests SPT in relation to gender and age ratings was made. Significant differences were found only among female children and adolescents; older adolescent girls showed better performance than younger ones in all subtests. Further details can be seen in tables 2 and 3 .

The results of the correlation between the scores of SPT and the forms of participation in situations of school violence indicate the existence of low negative correlations, however the most significant. The writing subtest score were negatively correlated, at significant 
Table 1: Qualitative analysis of the writing, arithmetic and reading subtests and total score of SPT expected for the grade in relation to sex and rank among children and adolescents

\begin{tabular}{|c|c|c|c|c|c|c|c|c|}
\hline \multirow{4}{*}{ Subtests } & \multicolumn{8}{|c|}{ Gender } \\
\hline & \multicolumn{4}{|c|}{ Boys $(n=189)$} & \multicolumn{4}{|c|}{ Girls (n=186) } \\
\hline & \multicolumn{2}{|c|}{ Children } & \multicolumn{2}{|c|}{ Adolescents } & \multicolumn{2}{|c|}{ Children } & \multicolumn{2}{|c|}{ Adolescents } \\
\hline & $\mathrm{n}$ & $\%$ & $\mathbf{n}$ & $\%$ & $\mathbf{n}$ & $\%$ & $\mathbf{n}$ & $\%$ \\
\hline \multicolumn{9}{|l|}{ Writing } \\
\hline Inferior & 82 & 71.3 & 64 & 86.5 & 90 & 72.6 & 48 & 77.5 \\
\hline Median & 27 & 23.5 & 10 & 13.5 & 31 & 25.0 & 11 & 17.7 \\
\hline Superior & 6 & 5.2 & 0 & 0.0 & 3 & 2.4 & 3 & 4.8 \\
\hline Total & 115 & 100 & 74 & 100 & 124 & 100 & 62 & 100 \\
\hline \multicolumn{9}{|c|}{ Arithmetical } \\
\hline Inferior & 86 & 74.8 & 68 & 91.9 & 100 & 80.7 & 57 & 91.8 \\
\hline Median & 25 & 21.7 & 6 & 8.1 & 20 & 16.1 & 4 & 6.6 \\
\hline Superior & 4 & 3.5 & 0 & 0.0 & 4 & 3.2 & 1 & 1.6 \\
\hline Total & 115 & 100 & 74 & 100 & 124 & 100 & 62 & 100 \\
\hline \multicolumn{9}{|l|}{ Reading } \\
\hline Inferior & 63 & 54.8 & 45 & 60.8 & 76 & 61.3 & 35 & 56.5 \\
\hline Median & 34 & 29.6 & 18 & 24.3 & 42 & 33.9 & 10 & 16.1 \\
\hline Superior & 18 & 15.7 & 11 & 14.9 & 6 & 4.8 & 17 & 27.4 \\
\hline Total & 115 & 100 & 74 & 100 & 124 & 100 & 62 & 100 \\
\hline \multicolumn{9}{|c|}{ Total score } \\
\hline Inferior & 89 & 77.4 & 74 & 100 & 101 & 81.5 & 58 & 93.5 \\
\hline Median & 22 & 19.1 & 0 & 0.0 & 22 & 17.7 & 4 & 6.5 \\
\hline Superior & 4 & 3.5 & 0 & 0.0 & 1 & 0.8 & 0 & 0.0 \\
\hline Total & 115 & 100 & 74 & 100 & 124 & 100 & 62 & 100 \\
\hline
\end{tabular}

Table 2: Description of raw scores of the subtests and total score of SPT in relation to gender and rank among children and adolescents

\begin{tabular}{lcccc}
\hline \multirow{2}{*}{ Subtests } & \multicolumn{2}{c}{ Boys $(\mathbf{n}=\mathbf{1 8 9})$} & Gender & \multicolumn{2}{c}{ Girls $(\mathbf{n}=\mathbf{1 8 6})$} \\
& Children & Adolescent & Children & Adolescent \\
\hline Writing & $19.84(8.73)$ & $20.66(9.55)$ & $20.40(8.24)$ & $23.85(8.49)$ \\
Arithmetical & $13.74(5.53)$ & $14.68(5.11)$ & $13.13(5.35)$ & $16.08(5.35)$ \\
Reading & $57.02(16.96)$ & $57.36(18.68)$ & $56.44(16.88)$ & $61.48(13.02)$ \\
Total score & $90.69(28.14)$ & $92.70(29.88)$ & $89.84(28.07)$ & $101.37(23.76)$ \\
\hline
\end{tabular}

Table 3: Comparisons of raw scores of the subtests and total score of SPT in relation to gender and rank among children and adolescent

\begin{tabular}{lcccc}
\hline Interest comparisons & Difference estimative & $\mathbf{p}$ Value & Confidence interval (95\%) \\
\hline Writing & & & & 1.73 \\
Male (Child-Adoles) & -0.81 & 0.52 & -3.36 & -0.79 \\
Female (Child-Adoles) & -3.45 & 0.01 & -6.12 & -0.24 \\
Children (Male-Fem.) & -0.55 & 0.62 & -2.76 & 0.63 \\
Adolesc. (Male-Fem.) & -3.19 & 0.03 & -13 & -1.31 \\
Arithmetical & & & -2.50 & 0.41 \\
Male (Child-Adoles) & -0.93 & 0.24 & -4.59 & 4.55 \\
Female (Child-Adoles) & -2.95 & 0.001 & -0.75 & -0.07 \\
Children (Male-Fem.) & 0.61 & 0.38 & -3.22 & 4.82 \\
Adolesc. (Male-Fem.) & -1.40 & 0.12 & & 1.53 \\
Reading & & & -5.24 & 6.13 \\
Male (Child-Adoles) & -0.34 & 0.88 & -10.15 & -3.02 \\
Female (Child-Adoles) & -5.04 & 0.05 & -9.77 & 7.92 \\
Children (Male-Fem.) & 0.57 & 0.79 & & 0.74 \\
Adolesc. (Male-Fem.) & -4.11 & 0.15 & -10.16 & -20.03 \\
Total score & & & -6.22 & -18.08 \\
Male (Child-Adoles) & -2.01 & 0.62 & \\
Female (Child-Adoles) & -11.53 & 0.001 & 0.81 & \\
Children (Male-Fem.) & 0.84 & 0.07 & & \\
Adolesc. (Male-Fem.) & -8.66 & & & \\
\hline
\end{tabular}


levels, with practicing and witnessing violent assaults at school. A similar result occurred in relation to the reading subtest. The arithmetic subtest score, in turn, correlated negatively and significantly with the three forms of participation in situations of school violence (assault, suffering beatings, and witnessing violence against peers). Finally, the total score obtained in SPT correlated negatively and significantly with practicing assaults and witnessing violence (table 4 and Figure 1).

Table 4: Correlations between the roles of participation in violent situations at school and school performance measures

\begin{tabular}{lccccccc}
\hline & 1 & 2 & 3 & 4 & 5 & 6 & 7 \\
\hline 1. Writing & 1.000 & $0.573^{* *}$ & $0.793^{* *}$ & $0.926^{* *}$ & $-0.138^{* *}$ & -0.100 & $-0.173^{* *}$ \\
2. Arithmetical & & 1.000 & $0.531^{* *}$ & $0.758^{* *}$ & $-0.139^{* *}$ & $-0.115^{*}$ & $-0.111^{*}$ \\
3. Reading & & & 1.000 & $0.896^{* *}$ & $-0.110^{*}$ & -0.057 & $-0.141^{* *}$ \\
4. Total SPT & & & & 1.000 & $-0.142^{* *}$ & -0.099 & $-0.154^{* *}$ \\
5. Spectator & & & & & 1.000 & $0.201^{* *}$ & $0.148^{* *}$ \\
6. Victim & & & & & & 1.000 & $0.471^{* *}$ \\
7. Aggressor & & & & & & & \\
\hline
\end{tabular}

Note. ${ }^{*} p<0.05 ;{ }^{* *} p<0.001$

Figure 1: Graphics correlation matrix between the roles of participation in violent situations at school and school performance measures

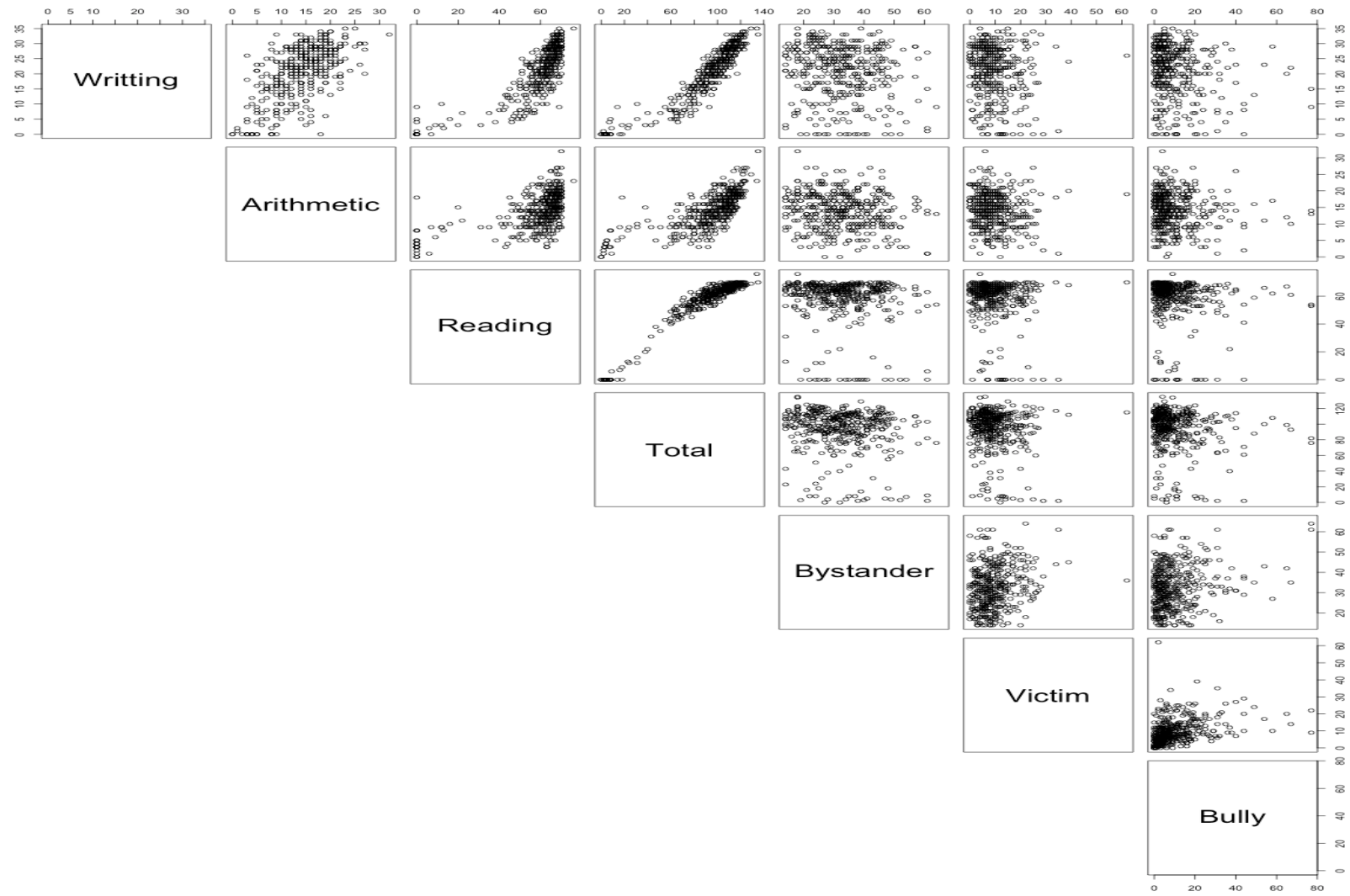

\section{DISCUSSION}

The data indicate that children and adolescents in a socially vulnerable situation showed, in relation to school performance, results below the expected levels for their respective school grade, with a predominance of the lowest rating for most students of both sexes and in different age groups on the three subtests (writing, arithmetic, and reading). In terms of comparison, the lowest occurred on the arithmetic subtest, whereas the results were less below par with respect to the reading subtest. Similar results were found by Capellini et al. ${ }^{17}$ study with a sample of students from a public school in São Paulo, and Ferreira, Conte and Marturano ${ }^{18}$ with a group of school children with behavioural problems in school.
Similarly, in the investigation by Silva et al. ${ }^{19}$ also carried out in the metropolitan region of Florianopolis, Santa Catarina, Brazil, in a peripheral location, the results also showed no significant differences between genders. However, was a composite sample only for students with a learning disability. The similarity between the results of this research and other studies presented, in which children and adolescents were evaluated with different profiles (however, they were all students of public schools), indicates that maybe the quality of public education is not suitable in locations considered socially vulnerable, but that is a more general and comprehensive problem.

Nevertheless, the literature indicates the performance was influenced not only by intra-school variables, 
in terms of the quality of education offered to students, as well as other variables related to the external environment, such as socioeconomic status, access to other social resources, and the social and cultural context of the children and adolescents of school age ${ }^{20}$. Independent of the causes of the poor performance of the participants of this study, the total score in the lower level for SPT they showed denotes difficulties encountered in learning and mastering the school content, which can hamper their social mobility, which is to say, their ability to leave the vulnerable condition in which they find themselves ${ }^{21}$.

However, in spite of the low results found on all the subtests of school performance, there was a difference between children and adolescents. The data indicated older girls performed better. However, the same was not observed among males. This indicates that low income was a feature that was present in the childhood and adolescence of the children in the study, which can remain stable for this group over the years.

Therefore, their respective trajectories in schooling can be a disadvantage, considering that several studies indicate that the lower the performance, the greater the chances of unbinding occurring over time, evasion and manifestation of behavioural problems, arising from frustration regarding the ability to learn ${ }^{10}$. Against the grain of this process, a good performance can have the effect of protecting, mitigating the relationship between school failure and the emergence of psychosocial and behavioural problems, and add to the positive educational experience, as well as increase interest in the content learned.

The results of the correlations between scores on the writing and reading subtests and participation in recurring situations of violence at school indicate that there is a significant relationship between school performance and engaging in assaults and witnessing violence at school. These findings are in line with other investigations that point to how poor performance is linked to greater involvement in school bullying ${ }^{10}$. Similarly, a survey conducted in Jamaica identified that aggressive students had higher educational disadvantages in terms of reading and writing skills and low educational aspirations. They were also more likely to demonstrate aggressive responses to received stimuli, at the expense of alternative answers, believing that these acts were positive results ${ }^{22}$.

It appears that poor performance correlates with committing aggressive acts. However, the data do not permit a finding of causation, which could clarify if poor performance makes the students more predisposed to commit aggressions against peers in school, or if the involvement in these situations is detrimental to performance. Most importantly, however, is signalling that children and adolescents with low performance, in addition to confronting problems in education, because of difficulties in learning and, for example, unbinding and truancy, may also have behavioural problems, such as engaging in acts of aggression, as has also been shown by the literature ${ }^{10}$.

In continuity, the results of the questionnaire on violence against peers in school also correlated with the results of reading and writing in SPT, indicating that children who witness violence tend to have lower performance. According to the literature, the bystanders are in- directly affected by situations of bullying, due to the emotional stress caused, as they may feel guilty for not helping the victim or abandoned by the school authorities. It helps make them feel unsafe at school and become distracted in class, hurting their school performance ${ }^{23}$. Other studies also attest to this relationship, noting that it can also lead to the development of feelings of aversion to school, and often problems related to evasion, techniques of neutralization (blaming the victim), believing in the effectiveness of violence in conflict resolution, and that, in the long run, these negative effects of witnessing violence in school can be as harmful as the damage caused by concrete experiences vivenced ${ }^{24}$. Although studies on bullying often direct its focus to the victims and aggressors, witnesses deserve attention because they represent the greatest number of people in relation to the other two profiles, and, as is demonstrated in this study, there is relationship between witnessing violence and the performance of these students.

Finally, the significant correlations between the arithmetic subtest scores with the three forms of participation in situations of school violence denote not only the low performance as a catalyst of involvement in bullying situations, as well as the difficulties that students face in learning content in mathematics, considering that more than $81 \%$ of them are located in the lower level in arithmetic. The results of the International Students Assessment (ISA), held in 2003, ranked Brazilian students in 40th place in mathematics of a total of 41 evaluated $^{25}$. In the 2013 edition of this program, Brazil improved modestly and was ranked in 38 th place among 44 countries. Despite the challenges faced, the poor performance in mathematics seems to affect students who have been victimized more, as it was the only performance subtest that significantly correlated to this group, while reading, writing, and total score of SPT correlated significantly with engaging in assaults and witnessing violence.

Despite the contributions made by this study to the national literature on the relationship between school performance and participation in situations of bullying among students in a socially vulnerable situation, especially considering the shortage of national publications as to these three themes, some limitations of the study need to be highlighted. The cross-sectional design prevents the drawing of inferences about the direction of the relationships identified, not allowing the establishment of causalities. Future research can adopt a longitudinal design, enabling the tracking of changes over time in order to identify the effects exercised by low school performance in involvement in bullying situations, identifying the relationships cause and effect.

Another limitation occurred by not assessing the situation of social vulnerability directly from the participants, with only the criteria adopted by the social programme that participated. Future studies can proceed in this direction. Similarly, no data was collected from other groups of students who did not submit social vulnerability, which limited the interpretation of the results; only information from the literature was used. This emphasizes the importance of conducting more quantitative studies aimed at addressing this limitation so that they can clarify the 
relationship between academic performance and bullying, with the objective of obtaining more explanatory data that can support prevention efforts and address these two problems in schools.

Despite such limitations, the results regarding correlations between school performance and participation in situations of bullying (victims, bullies, and bystanders) reinforce the relevance of the theme. And they confirm the indications that bullying is a public health problem because of its high prevalence and the damage it causes to the healthy development and psychosocial well-being of children and adolescents. ${ }^{5}$ Identifying different forms of manifestation of violence against children and adolescents and how they affect their lives is essential to providing care. Thus, the results obtained in this study can help in the development of intervention programmes linked to health promotion strategies and the completeness of the care at school, in the perspective of an emancipatory model, which seeks the empowerment and participation of the subjects involved. Important perspective for changes of trajectories of social vulnerability or involving violence, especially if it is understood as one dimension which integrates multiple sectors and involves macro-structural aspects (the example of public social policies), as the articulation and integration of different sectors and services in the context of an inter-sectoral and integral approach by defining and establishing networks of support and protection.

The relevance of this study consists in contributing to an approach to the relationship between academic per- formance and bullying in different age groups who live in a specific context of social vulnerability. It is suggested that this issue should be studied from this point of view in order to have more data to compare the phenomenon in different groups and social strata, in addition to broadening our understanding of what causes or elicits this social practice in the school environment.

\section{CONCLUSION}

Based on the results found in this research, which identified that the majority of children and adolescents in a socially vulnerable situation investigated in this study perform in school at a level considered lower than what is expected for the school grade that they attend. With such results, it was found that teenage girls showed better performance in relation to children of the same gender; however, the same was not verified among the boys. Furthermore, it was found the existence of relationships between low school performance and participation in bullying situations in which those involved assumed different roles vis-à-vis this phenomenon (victim, attacker, and spectator). It appeared from the results that there is a need to improve the performance of the students investigated, with a view not only to increasing the chances of progressing personally and professionally, considering the situation of social vulnerability, as well as to avoid involvement in situations of school violence.

\section{REFERENCES}

1. Olweus D. School bullying: Development and some important challenges. Annu Rev Clin Psychol. 2013;9:751-80. DOI: http://dx.doi.org/10.1146/annurev-clinpsy-050212-185516

2. Kärna A, Voeten M, Little TD, Poskiparta E, Kaljonen A, Salmivalli C. Going to Scale: A Nonrandomized Nationwide Trial of the KiVa Antibullying Program for Grades 1-9. J Consult Clin Psychol. 2013;79(6): 796-805. DOI: http://dx.doi.org/10.1037/a0025740

3. Lopes Neto A. Bullying: comportamento agressivo entre estudantes. J Pediatr (Rio J). 2005; 81 (5 Suppl.):s 164-72. DOI: http://dx.doi.org/10.1590/S0021-75572005000700006

4. Fisher RM. Bullying escolar no Brasil: relatório final. São Paulo: CEATS/FIA; 2010.

5. Oliveira WA, Silva MAI, Mello FCM, Porto DL, Yoshinaga ACM, Malta DC. The causes of bullying: results from the National Survey of School Health (PeNSE). Rev Latino-Am Enfermagem. 2015;23(2): 275-82. DOI: http://dx.doi.org/10.1590/0104-1169.0022.2552

6. Boarini ML. Indisciplina escolar: uma construção coletiva. Psicol Esc Educ. 2013;17(1): 123-31.

7. Antunes DC, Zuin AAS. Do Bullying ao preconceito: os desafios da barbárie à educação. Psicol Soc. 2008; 20(1): 16-3.

8. Félix EMR, Alamillo RDR, Ruiz RO. Prevalencia y aspectos diferenciales relativos algénerodel fenómeno bullyingen países pobres. Psicothema. 2011; 23(4): 624-29.

9. Capellini SA, Tonelotto JMF, Ciasca SM. Medidas de desempenho escolar: avaliação formais e opinião dos professores. Estud Psicol. 2004;21(2):79-90. DOI: http://dx.doi.org/10.1590/S0103-166X2004000200006

10. Yang KM, Chung H, Kim U. The effects of school violence on the psychological adjustment of Korean adolescents: A comparative analysis of bullies, victims, and bystanders. In: Yang KS, Hwang KK, Pedersen PB, Daibo I. Progress in Asian social psychology: conceptual and empirical contributions. Westport: Greenwood Publishing Group; 2003; p.263-75.

11. Soares JF, Alves MTG. Desigualdades raciais no sistema brasileiro de educação básica. Educ Pesqui. 2003;29(1):147-65. DOI: http://dx.doi.org/10.1590/S1517-97022003000100011

12. StocoS, Almeida LC. Escolas municipais de Campinas e vulnerabilidade sociodemográfica: primeiras aproximações. Rev Bras Educ. 2011;16(48):663-94. DOI: http://dx.doi.org/10.1590/S1413-24782011000300008

13. Marturano EM. A criança, o insucesso escolar precoce e a família: condições de resiliência e vulnerabilidade. In: Marturano EM, Loureiro SR, Zuardi AW. Estudos em saúde mental. Ribeirão Preto: Comissão de Pós-Graduação em Saúde Mental da FMRP/USP; 1997; p.130-49. 
14. Stein LM. TDE: teste de desempenho escolar: manual para aplicação e interpretação. São Paulo: Casa do Psicólogo; 1994.

15 Giacomoni CH, Athayde ML, Zanon C, Stein LM. Teste do Desempenho Escolar: evidências de validade do subteste de escrita. Psico-USF. 2015;20(1):133-40.

16. Freire IP, Simão AMV, Ferreira AS. O estudo da violência entre pares no $3^{\circ}$ ciclo do ensino básico: um questionário aferido para a população escolar portuguesa. Rev Port Educ. 2006;19(2):157-83.

17. Capellini S, Tonelotto J, Ciasca S. Medidas de desempenho escolar: avaliação formais e opinião dos professores. Estud Psicol. 2004;21(2):79-90. DOI: http://dx.doi.org/10.1590/S0103-166X2004000200006

18. Ferreira AA, Conte KM, Marturano EM. Meninos com queixa escolar: autopercepções, desempenho e comportamento. Estud Psicol. 2011;28(4):443-51. DOI: http://dx.doi.org/10.1590/S0103-166X2011000400005

19. Silva JD, Beltrame TS, Oliveira AVP, Sperandio FF. Motor and learning disabilities in school children with low academic performance. Rev Bras crescimento Desenvolv Hum. 2012;22(1):41-46. DOI: http://dx.doi.org/10.7322/jhgd.20048

20. Coley RL, Morris JE, Hernandez D. Out-of-school care and problem behavior trajectories among low income adolescents: individual, family, and neighborhood characteristics as added risks. Child Dev. 2004;75(3):948-65. DOI: http://dx.doi.org/10.1111/j.1467-8624.2004.00716.x

21. Rota Júnior, C. Educação e mobilidade social: estudo sobre a legislação educacional brasileira. Educ Soc Cult. 2013;(38):169-84.

22. Gardner JM, Powell CA, Grantham-McGregor SM. Determinants of aggression and pro social behavior among Jamaican school boys. West Indian Med J. 2007;56(1):34-41.

23. Kohut MR. The Complete guide to understanding, controlling, and stopping bullies \& Bullying: a completeguide for teachers \& parents. Ocala: Atlantic; 2007.

24. Mrug S, Windle M. Bidirectional influences of violence exposure and adjustment in early adolescence: externalizing behaviors and school connectedness. J Abnorm Child Psychol. 2009;37(5):611-23. DOI: http://dx.doi.org/10.1007/s10802-009-9304-6

25. Brooke N. O futuro das políticas de responsabilização educacional no Brasil. Cad Pesqui. 2006;36(128):377401. DOI: http://dx.doi.org/10.1590/S0100-15742006000200006

This article is distributed under the terms of the Creative Commons Attribution 4.0 International License (http://creativecommons.org/licenses/by/4.0/), which permits unrestricted use, distribution, and reproduction in any medium, provided you give appropriate credit to the original author(s) and the source, provide a link to the Creative Commons license, and indicate if changes were made. The Creative Commons Public Domain Dedication waiver (http://creativecommons.org/publicdomain/zero/1.0/) applies to the data made available in this article, unless otherwise stated. 


\section{Resumo}

Introdução: O bullying escolar é caracterizado pela repetitividade das agressões ao longo do tempo, pela intencionalidade em se ferir ou causar sofrimento ao outro e pelo desequilíbrio de poder entre as partes envolvidas. Não se trata de um fenômeno atual, pois as situações recorrentes de violência entre pares na escola provavelmente acompanham a história dessa instituição. O envolvimento no bullying escolar pode trazer consequências negativas, inclusive, para o processo de ensino-aprendizagem dos estudantes, no qual os envolvidos podem apresentar baixo desempenho, reprovação ou abandono escolar, assim como episódios de indisciplina.

Objetivo: identificar o desempenho escolar de crianças e adolescentes em situação de vulnerabilidade social, bem como, analisar as possíveis relações deste desempenho escolar com a participação em situações de violência que caracterizem bullying.

Método: Participaram 375 crianças e adolescentes do Ensino Fundamental, de ambos os sexos, com idades entre 8 e 16 anos. Os instrumentos utilizados foram: Teste de Desempenho Escolar, Escala Sociométrica e Questionário para o Estudo da Violência Entre Pares. Os dados foram analisados por meio dos testes ANOVA-Two way e correlação de Spearman.

Resultados: O presente estudo indicou que as crianças e adolescentes em situação de vulnerabilidade social apresentaram em relação ao desempenho escolar resultados abaixo dos níveis esperados nos três subtestes: escrita, aritmética e leitura, em ambos os sexos e nos diferentes grupos etários. Em uma análise intra e extra-grupo, verificou-se uma diferença significativa entre crianças e adolescentes do sexo feminino em todos os subtestes. Entretanto, o mesmo não foi verificado entre os meninos. Também se verificou relações entre baixo desempenho escolar e participação em situações de bullying, nos quais foi encontrado que o escore no subteste de escrita esteve correlacionado negativamente com praticar agressões e testemunhar violência na escola. Resultado semelhante ocorreu em relação ao subteste de leitura. O escore do subteste de aritmética, por sua vez, correlacionou-se negativa com as três formas de participação em situações de violência escolar: agredir, sofrer agressões e testemunhar violência contra os colegas. Por fim, o escore total obtido no TDE correlacionou-se negativamente de forma significativa com praticar agressões e testemunhar violência.

Conclusão: Com base nos resultados encontrados no presente manuscrito, identificou-se que a maioria das crianças e adolescentes em situação de vulnerabilidade social investigados neste estudo, apresentaram desempenho escolar em nível considerado inferior ao esperado para a série/ano que frequentavam. Aliado a tais resultados, verificou-se que meninas adolescentes apresentaram melhor desempenho em relação as crianças do mesmo sexo. Ademais, verificou-se a existência de relações entre baixo desempenho escolar e participação em situações de bullying nas quais os envolvidos assumiam diferentes perfis perante este fenômeno: vítima, agressor e espectador.

Palavras-chave: escolaridade, bullying, vulnerabilidade social. 